\title{
PENERAPAN PROBLEM BASED LEARNING DALAM MENINGKATKAN HASIL BELAJAR MATEMATIKA SISWA SEKOLAH DASAR
}

\author{
Theodosia Ndole ${ }^{1}$, Maria Ana ${ }^{2}$ \\ ${ }^{1}$ Guru SDK Ndona 2, Jl. Trans Wolowona- Ndona \\ ${ }^{2}$ Kepala Sekolah SDK Ndona 2, Jl. Trans Wolowona-Ndona \\ theodosindole06@gmail.com, 05mariaana@gmail.com
}

\begin{abstract}
This research was conducted to improve the mathematics learning outcomes of elementary school students by using the Problem Based Learning model. The method used in this research is Classroom Action Research. Class IV SDK Ndona 2 students totalling 16 students are the subjects in this study. The results before the action were taken, namely, in the pre-cycle, only 6 students or $37.5 \%$ completed, in the first cycle increased to 10 students or $62.5 \%$ who completed learning mathematics and in the second cycle increased again to 14 students who completed learning mathematics or $87,5 \%$. This study is said to be successful because it achieves performance indicators, namely $\geq 80 \%$ of all students with a minimum standard of $\geq 70$. Based on the results of the study, it can be concluded that learning with the Problem Based Learning model can improve learning outcomes in mathematics students.
\end{abstract}

Keywords: Mathematics Learning Results; Problem Based Learning

\begin{abstract}
Abstrak
Penelitian ini dilaksanakan untuk meningkatkan hasil belajar matematika siswa Sekolah Dasar dengan menggunakan model Problem Based Learning. Metode yang digunakan dalam penelitian ini ialah Penelitian Tindakan Kelas.. Siswa kelas IV SDK Ndona 2 yang berjumlah 16 siswa merupakan subjek dalam penelitian ini. Hasil sebelum dilakukan tindakan yaitu pada pra siklus hanya 6 siswa atau 37,5\% yang tuntas, pada siklus I meningkat menjadi 10 siswa atau $62,5 \%$ yang tuntas belajar matematika dan pada siklus II meningkat lagi menjadi 14 siswa yang tuntas belajar matematika atau $87,5 \%$. Indikator pencapaian siswa $u \geq$ $80 \%$ dari seluruh siswa dengan KKM $\geq 70$ maka penelitian ini dinyatakan telah memenuhi kriteria keberhasilan dan dihentikan tindakannya pada siklus ke II. Berdasarkan hasil penelitian dapat disimpulkan bahwa pembelajaran dengan model Problem Based Learning dapat meningkatkan hasil belajar pada mata pelajaran matematika siswa.
\end{abstract}

Kata kunci: Hasil Belajar Matematika; Problem Based Learning

\section{PENDAHULUAN}

Matematika sebagai ilmu pengetahuan memiliki peranan yang sangat urgent dalam aplikasinya pada kehidupan sehari-hari. Matematika sebagai ilmu pengetahuan memberikan sumbangsih yang besar baik dalam aplikasinya yang sederhana hingga ke yang lebih kongkrit. Matematika sebagai mata pelajaran yang telah diperkenalkan kepada siswa sejak tingkat sekolah dasar sampai ke pendidikan tinggi (Amir, 2014:73)

Jenjang pendidikan sekolah dasar menekankan pembelajaran matematika pada pembentukan karakter yang berkaitan dengan logika, sikap, dan ketrampilan. Tak dapat dipungkiri bahwa 
Keberhasilan pencapaian hasil belajar matematika yang baik dalam kegiatan belajar mengajar dipengaruhi oleh dua faktor yaitu faktor dalam diri siswa dan faktor dari luar diri siswa (eksternal). Faktor dalam diri siswa yang mempengaruhi hasil belajar antara lain minat, bakat, keterampilan, usaha, motivasi, perhatian dan kesehatan. Faktor dari luar siswa yang mempengaruhi hasil belajar antara lain lingkungan fisik dan non fisik (Mulyanto, Gunarhadi \& Indriayu, 2018:43). Penyajian dalam pembelajaran matematika di sekolah disesuaikan dengan perkiraan perkembangan intelektual siswa. Salah satu yang paling disarankan ialah mengaitkan materi pembelajaran yang disampaikan dengan realita kehidupan di sekitar siswa atau disesuaikan dengan tingkatan usia siswa (Rahmah, 2013:4). Hal ini berhubungan dengan Pengalaman yang telah diperoleh siswa dalam kehidupannya sehari-hari. Sebagai siswa, matematika memainkan peran penting dalam cara guru matematika mempertimbangkan apa artinya mengetahui, melakukan, dan mengajar matematika. Dengan demikian, memahami pengalaman masa lalu dan cara untuk bekerja dengannya dalam pendidikan guru merupakan perhatian yang kritis (Valentine \& Bolyard, 2019).

Berpikir analitis, logis, kritis, analitis, dan kreatif serta memiliki kemampuan untuk bekerjasama merupakan karakter yang ingin ditanamkan dalam proses pembelajaran matematika. Semua kompetensi tersebut diharapkan dapat membantu siswa kelak dalam penerapannya dalam kehidupannya sehari-hari, maupun dalam dunia kerja nanti (Etherington, 2011). Wahyudin (2008) berpendapat bahwa dalam penerapannya, guru memiliki kewajiban tertinggi untuk mengatur dan merancang proses pembelajaran dengan merepakan metode, menggunakan media maupun menyusun rencana pembelajaran yang mampu mendukung suasana belajar yang kondusif. Sagala (2011) berpendapat bahwa salah satu bentuk penerapan pembelajaran yang baik ialah dengan menggunakan metode atau model pembelajaran yang tepat, yang mampu membangun kompetensi belajar siswa yang diinginkan.

Salah satu model pembelajaran yang disarankan dalam mengembangkan kemampuan hasil belajar siswa ialah Problem Based Learning (PBL). Menurut Suradijono (2004) Problem based lerning melibatkan masalah baru, yang kemudian dikombinasikan dengan pengetahuan yang telah diperoleh siswa sehari-hari dan dikombinasikan untuk menemukan pengetahuan baru sebagai solusi dari permasalahan yang diberikan (Krismiati, 2008). Menurut Boud \& Felleti (1997) menyatakan bahwa PBL membangun proses pembelajaran menggunakan masalah sebagai stimulus dan fokus pada aktivitas siswa.

Padmavathy \& Mareesh (2013) menunjukkan bahwa model pembelajaran berbasis masalah lebih efektif dalam pengajaran matematika. Dengan mengadopsi model pembelajaran berbasis masalah dalam pembelajaran, guru matematika dapat melakukannya merangsang siswa untuk berpikir kreatif, membuat keputusan penting, dan memecahkan masalah yang mendesak kompetisi dunia. Selain itu, strategi pembelajaran berbasis masalah mempengaruhi pengetahuan siswa yang 
memberikan kesempatan lebih besar bagi siswa untuk belajar. Mereka juga punya kesempatan untuk lebih terlibat dan untuk meningkatkan partisipasi aktif, motivasi, dan minat di antara mereka. Itu membuat para siswa memiliki sikap positif terhadap matematika dan membantu mereka untuk meningkatkan prestasi mereka menghasilkan memori jangka panjang. Ini juga memberikan pengalaman baru dan yang diinginkan bagi siswa (Nurlaily, Soegiyanto \& Usodo, 2019)

Problem based learning membuat siswa belajar melalui aktivitas penyelesaian masalah, sehingga membuat keterampilan berpikir siswa semakin diasak (Rahmadani, 2017:241). PBL membuat siswa harus terlibat dalam aktif dalam proses pembelajarannya, dikarenakan PBL menggunakan media kelompok kolaboratif sebagai bagian dari metode pembelajaran. Siswa saling bertukar pikiran dan memberikan solusi melalui pengalan yang telah diperoleh untuk menemukan solusi.

Menurut Schmidt, Rotgans \& Yew (2011), secara umum penerapan model pembelajaran ini dimulai dengan masalah awal sehingga siswa dituntut aktif mencari informasi mengenai permasalahan tersebut. Selanjutnya, siswa mendiskusikan informasi yang diperoleh untuk mencari solusi permasalahan.selain itu. Rusman (2014:229) berpendapat bahwa PBL sebagai model pembelajaran yang melibatkan siswa dalam belajar kolaboratif, mampu mengembangkan kompetensi komunikatif siswa dalam membangun ilmu pengetahuan, dengan melibatkan pengetahuan yang pernah diperoleh mereka. Hal ini membuat siswa semakin berikir lebih kritis dan mampu membentuk pengathuan baru sebagai solusi pemecahan masalah yang diberikan (Suhirman, Prayogi \& As'yari, 2021). Menurut Howard (2002) bahwa dalam PBL, siswa mampu secara bersamaan mengembangkan strategi pemecahan masalah. PBL mengharuskan siswa untuk menggunakan pengetahuan dan keterampilan yang mereka peroleh dalam konteks yang bermakna. PBL melibatkan siswa dalam kegiatan berbasis inkuiri untuk mendorong pemahaman yang mendalam tentang sains dan untuk mengembangkan sikap dan nilai-nilai sosial yang kondusif bagi pembelajaran (Drake \& Long, 2009).

Fauziah (2018: 44-45) dalam hasil analisis penelitiannya menyimpulkan bahwa pembelajaran dengan model problem based learning (PBL) mampu meningkatkan hasil belajar matematika siswa sekolah dasar. PBL mampu mengembangkan kemampuan berpikir kritis siswa serta dapat menumbuhkan motivasi peseta didik dalam pembelajaran (Asriningtyas, Kristin \& Anugraheni, 2018: 31) (Arif, Maulana \& Sudin, 2016: 149). Lebih lanjut, Pratama, Lestari \& Jailani (2018: 19) dalam hasil penelitiannya mengungkapkan bahwa melalui pembelajaran PBL, siswa terdorong untuk aktif dalam pembelajaran, sehingga berdampak positif pada minat belajar matematika serta peningkatan kemampuan kognitif yakni prestasi belajar siswa (Meke, et. al. (2018) (Mashuri, Djidu \& Ningrum, 2019: 123) (Meke, et. al., 2019).

(Mulyanto, Gunarhadi \& Indriayu, 2018:43-44 dalam hasil penelitiannya pada matematika sekolah dasar menyatakan siswa yang mengikuti model Problem Based Learning memperoleh hasil 
belajar yang lebih tinggi daripada siswa yang mengikuti model konvensional. Hal ini dikarenakan PBL mampu membangun keterampilan berpikir kritis siswa sekolah dasar. Siswa yang memiliki keterampilan berpikir kritis tinggi memperoleh hasil belajar yang lebih baik (Hasannah, Sofelma \& Syarifuddin, 2021:980).

\section{METODE}

Penelitian ini menggunakan metode Penelitian Tindakan Kelas (PTK) (Kemmis \& Mc. Taggart, 1988). Subjek penelitian adalah siswa kelas IV SDK Ndona 2 dengan jumlah 16 siswa yang terdiri dari 7 siswa laki-laki dan 9 siswa perempuan. PTK yang dirancang menggunakan 3 siklus. Dalam setiap siklus terdapat 3 tahap umum yakni tahap perencanaan, tahap pelaksanaan (termasuk tahap observasi, dan tahap refleksi (Ekawarna, 2013:5).

Tahap perencanaan memuat seluruh perancangan terhadap perangkat pembelajaran yang dibutuhkan menggunakan model Problem based learning. Peneliti bersama guru kelas merancang perangkat pembelajaran serta lembar observasi dan Lembar kerja siswa berseting PBL. Sementara itu dalam tahap pelaksanaan, semua perangkat yang telah disusun, diaplikasikan sesuai rencana yang telah dibuat. Peneltii dan guru bersama-sama melakukan kegiatan observasi dan juga pembelajaran sesuai dengan RPP dan rancangan yang telah disusun berimplementasi pembelajaran problem based learning (Arikunto, 2006).

Lebih lanjut dalam tahap refleksi, guru dan peneliti bersama-sama melihat kembali hasil dan susunan rancangan perangkat pembelajaran, kemudian mulai mengevaluasi serta memperbaiki segala kekurangan dalam tahap pelaksanaan guna perancangan dan pelaksanaan yang lebih baik pada siklus berikutnya. Dalam penelitian ini, data yang diperoleh ialah data hasil observasi dan tes hasil belajar siswa berimplementasi PBL. Yang diperoleh melalui teknik observasi dan tes. Lebih lanjut, analisis data pada penelitian ini menggunakan teknik analisis data kualitatif dan kuantitatif (Moleong, 2007).

\section{HASIL DAN PEMBAHASAN}

\section{Analisis Ketuntasan Hasil Belajar Matematika Siklus I}

Ketuntasan hasil belajar yang didapat dari analisis ketuntasan pra siklus sampai siklus II yakni pra siklus sebelum menggunakan model Problem Based Learning terjadi hasil belajar siswa yakni yang tuntas 6 orang dan yang tidak tuntas 10 orang dengan nilai tertinggi 79 dan nilai terendah 52, rata-rata 67 serta persentase ketuntasan adalah 37,5\%. Setelah melakukan perbaikan dengan meneggunakan model Problem Based Learning terjadi peningkatan pada yaitu pada siklusI jumalah siswa yang tuntas meningkat menjadi 9 orang dan yang tidak tuntas berjumlah 7 orang dan nilai tertinggi 85 dan nilai terendah 60 dengan rata-rata 72 dan persentase ketuntasan adalah 56,25\% dan setelah pelaksanaan perbaikan siklus II dengan indikator yang berbeda terjadi peningkatan hasil 
belajar yakni siswa yang tuntas berjumlah 13 orang dan siswa yang tidak tuntas berjumlah 3 orang, nilai tertinggi 90 dan nilai terendah 65 serta rata-rata 78. Jumlah persentase ketuntasan pada siklus II yaitu $81,25 \%$ dan telah mencapai indikator pencapaian yang telah di rencanakan.

Analisis data setelah melakukan perbaikan pada siklus I menggunakan model Problem BasedLearning mengalami peningkatan. Untuk lebih jelas dapat di lihat pada tabel 2.

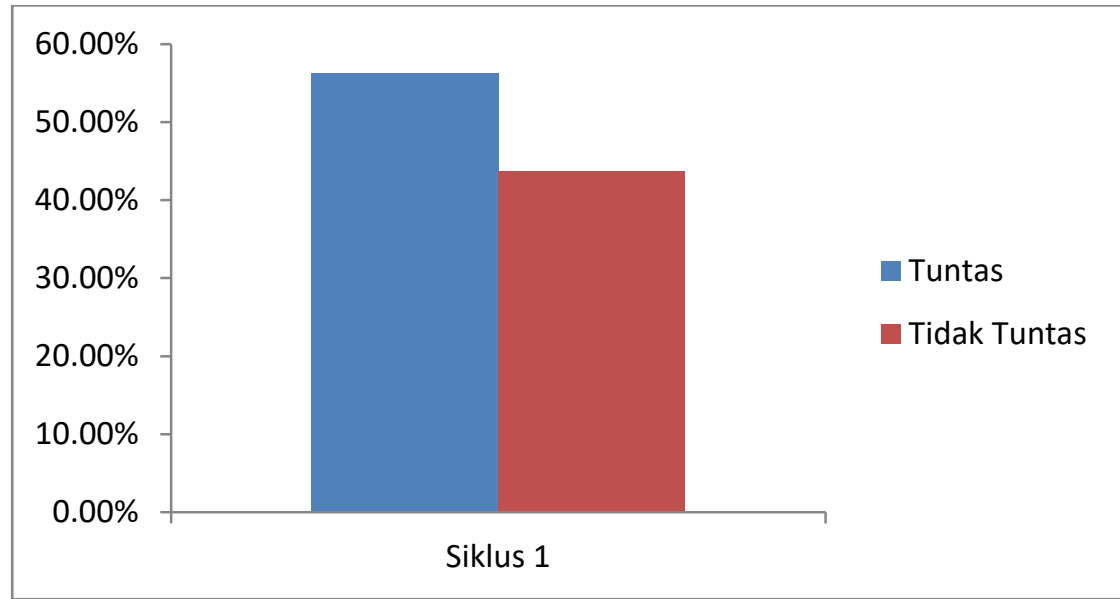

\section{Gambar 1. Distribusi Ketuntasan Hasil Belajar Matematika Siklus I}

Gambar 1 menunjukan adanya peningkatan hasil belajar matematika siswa SD. Dari 16 subjek penelitian, sebanyak 56,25\% siswa dinyatakan memenuhi kriteria ketuntasan

\section{Analisis Ketuntasan Hasil Belajar Matematika Siklus II}

Berdasarkan analisis data setelah melakukan perbaikan pembelajaran siklus II, terjadi peningkatan hasil belajar, jika di bandingkan dengan hasil belajar pra siklus dan siklus I. Untuk lebih rinci dapat melihat pada gambar 2 .

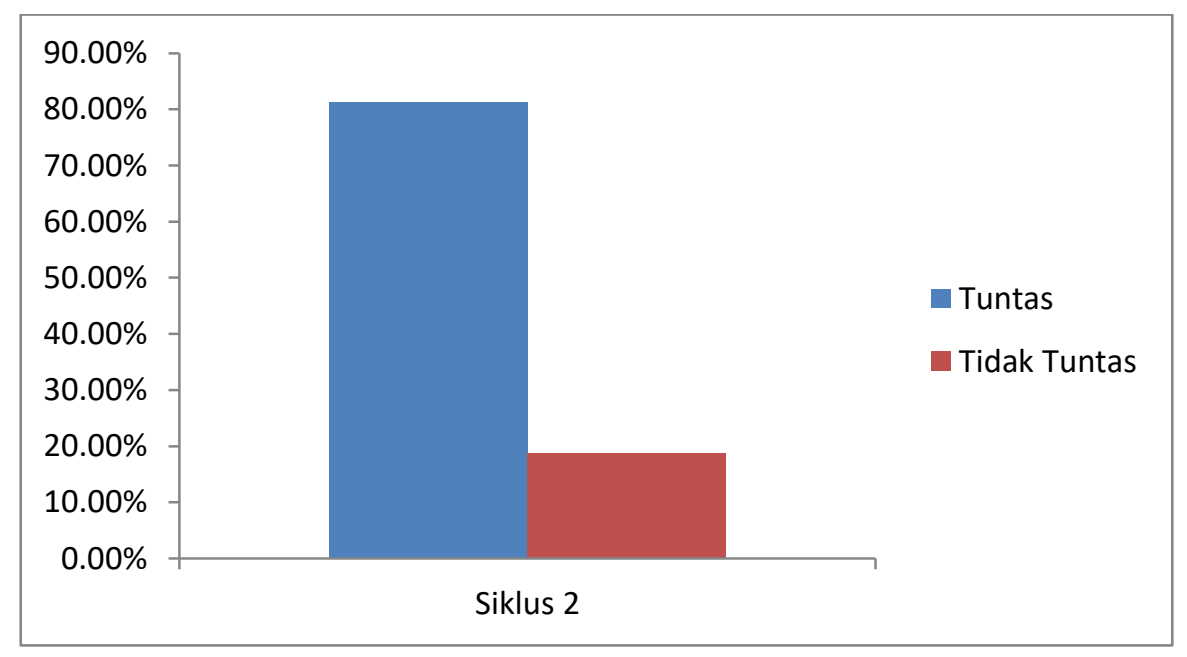

Gambar 2. Distribusi Ketuntasan Hasil Belajar Matematika Siklus II 
Gambar 2 menunjukan adanya peningkatan yang signifikan pada hasil belajar siswa setelah diterapkannya pembelajaran PBL. Lebih dari $80 \%$ siswa mengalami peningkatan pembelajaran dan dinyatakan memenuhi kriteria ketuntasan minimal belajar siswa.

\section{Analisis Komparatif}

Berdasarkan analisis hasil belajar dari pra siklus, siklus I dan siklus II. Analisis menggunakan data hasil kuantitas hasil belajar dari pra siklus, siklus I dan siklus II. Untuk rincinya dapat di lihat pada tabel 4.

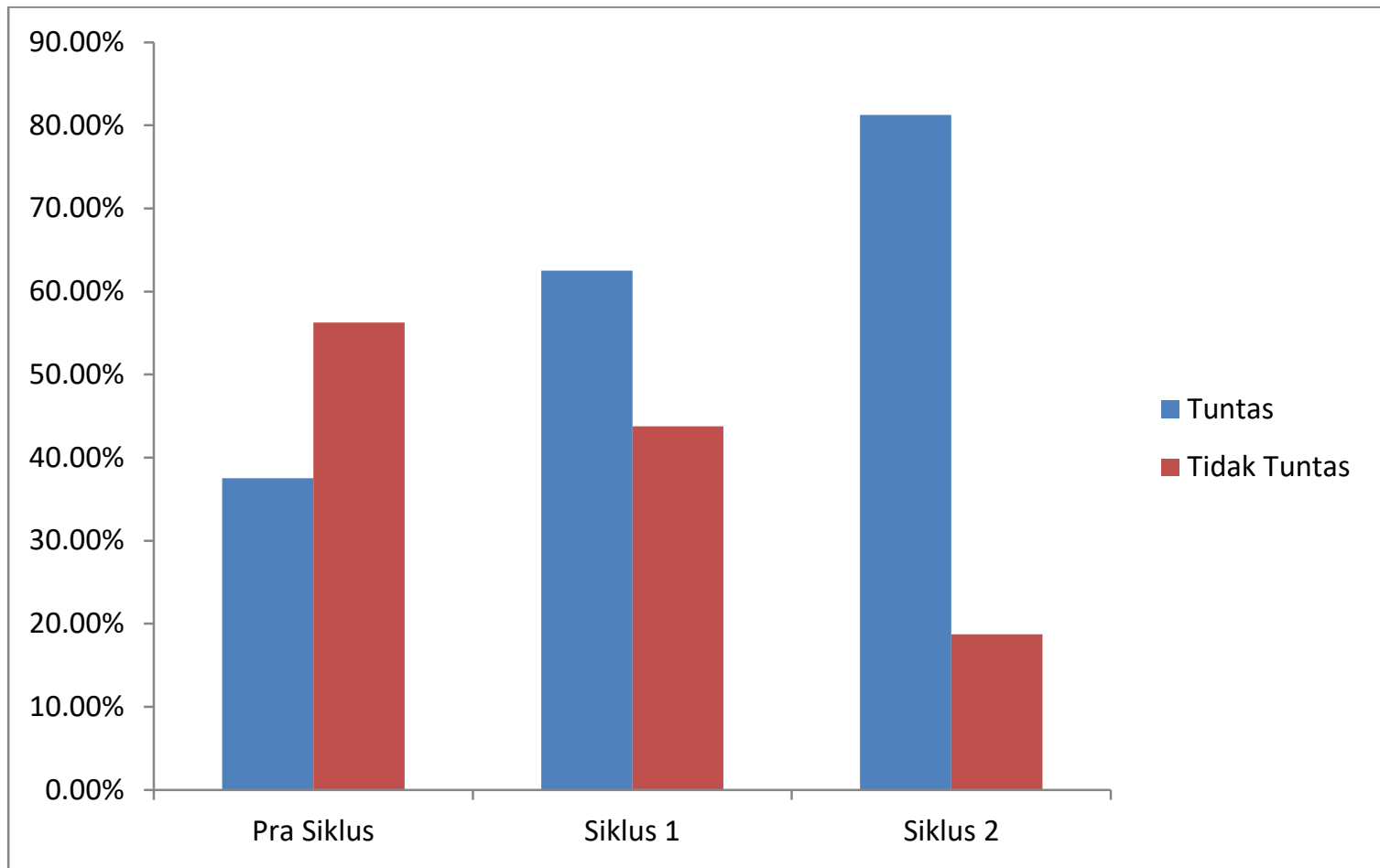

\section{Gambar 3. Analisis Komparatif Ketuntasan Hasil Belajar Matematika Siswa}

Pada gambar 3, dijelaskan bahwa PBL mampu meningkat hasil belajar siswa dalam keseluruhan proses pembelajaran matematika sekolah dasar (Maret \& Syarifuddin, 2021). Hasil pembelajaran siswa mengalami peningkatan ditiap tahap siklus pembelajaran. Siklus 2 mengalami peningkatan keberhasilan siswa sebesar 25\% dibandingkan dengan siklus 1 . Hal ini membuktikan bahwa PBL dapat meningkatkan hasil belajar matematika siswa sekolah dasar (Ismiyono, 2020). Peningkatan hasil belajar siswa dari 37,5\% (6 Siswa) tuntas pada pra sisklus hinga menjadi 81,25\% (13 Siswa) tuntas pada siklus II menjadi acuan yang cukup baik dalam meningkatkan hasil belajar siswa.

PBL menjadi model pembelajaran yang mampu meningkatan Hail belajar siswa dalam belajar matematika, karena menggunakan masalah sehari-hari sebagai isu utama dalam proses pembelajaran (Meke, Wondo \& Wutqa, 2020: 173). Model problem based learning membantu mendorong siswa untuk belajar secara aktif dalam situasi kolaboratif (Meke \& Wondo, 2020:596). Faktor lain yang 
menyebabkan ketercapaian tujuan pembelajaran dengan model problem-based learning (PBL) adalah adanya kegiatan pembelajaran yang bermakna, di mana siswa terlibat secara aktif dalam proses diskusi untuk mengidentifikasi masalah, memahami masalah, dan menyelesaikannya dengan memanfaatkan berbagai sumber pengetahuan dan sumber informasi sehingga pada akhirnya memperoleh pengetahuan baru. Kebermaknaan PBL ini sesuai dengan karakteristik dari PBL itu sendiri yang menghadirkan masalah-masalah dunia nyata dalam pembelajaran (Wondo, 2017: 83)

\section{KESIMPULAN}

Berdasarkan hasil penelitian dan pembahasan, maka dapat disimpulkan bahwa dengan menggunakan model Problem Based Learning dapat meningkatkan hasil belajar matematika materi bangun datar pada siswa kelas IV SDK Ndona 2 Kecamatan Ndona Kabupaten Ende. Hal ini dapat dibuktikan dengan perolehan nilai hasilbelajar matematika siswa setelah diberikan tindakan pada tiap siklus. Penggunaan langkah-langkah model Problem Based Learning dapat meningkatkan hasil belajar matematika materi bangun datar pada siswa kelas IV SDK Ndona 2 Kecamatan Ndona Kabupaten Ende. Hal ini terjadi karena beberapa langkah-langkah penggunaan model Problem Based Learning sudah terlaksana dengan baik. seperti; (1) siswa mendengarkan permasalahan yang diberikan oleh guru. (2) siswa secara aktif menjawab dari pemecahan masalah tersebut. (3) siswa duduk secara berkelompok sesuai yang telah ditentukan oleh guru. (4) siswa mendefinisikan dan mengorganisasikan tugas- tugasnya yang berhubungan dengan masalah. (5) siswa mengumpulkan informasi dan data-data yang diperlukan untuk pemecahan masalah. (6) siswa menyusun laporan dalam kelompok dan menyajikannya dihadapan kelas dan berdiskusi dalam kelas. Saran yang dapat peneliti berikan berdasarkan penelitian yang telah dilakukan adalah agar guru menggunakan modelmodel pembelajaran yang inovatif dalam pembelajaran sehingga dapat membantu siswa untuk menerapkan ilmu yang telah diperoleh dalam kehidupan nyata.

\section{DAFTAR PUSTAKA}

Amir, A. (2014). Pembelajaran Matematika Sd Dengan Menggunakan Media Manipulatif. Forum Paedagogik. 6(1), 72-89

Arief, H. S., Maulana, M. \& Ali Sudin, A. (2016). Meningkatkan Motivasi Belajar Melalui Pendekatan Problem-Based Learning (PBL). Jurnal Pena Ilmiah. 1(1), 141-150

Arikunto, S. (2006). Penelitian Tindakan Kelas, Jakarta: Bumi Aksara

Arista, Khoirul. (2018). Penerapan Model Pembelajaran Problem Based Learning untuk Meningkatkan Tanggung Jawab dan Hasil Belajar Siswa Kelas 2 SD. Jurnal Kajian Penelitian Pendidikan Dan Pembelajaran, 2, 195-196.

Asriningtyas1, A. N., Kristin, F. \& Anugraheni, I. (2018). Penerapan Model Pembelajaran Problem 
Based Learning Untuk Meningkatkan Kemampuan Berpikir Kritis dan Hasil Belajar Matematika Siswa Kelas 4 SD. JKPM: Jurnal Karya Pendidikan Matematika. 5(1), 23-32.

Boud, D., \& Feletti, G. (Ed.). (1997). The challenge of problem-based learning. London: Kogan Page

Drake, K. N., \& Long, D. (2009). Rebecca's in the dark: A comparative study of problem-based learning and direct instruction/experiential learning in two 4th-grade classrooms. Journal of Elementary Science Education, 21(1), 1-16. doi:10.1007/bf03174712

Ekawarna. 2013. Penelitian Tindakan Kelas. Jakarta: Referensi (GP Press Group)

Etherington, M. B. (2011). Investigative primary science: A problem-based learning approach. Australian Journal of Teacher Education (Online), 36(9), 53-74. https://search.informit.org/doi/10.3316/ielapa.328484780726539

Fauzia, H. A. (2018). Penerapan Model Pembelajaran Problem Based Learning Untuk Meningkatkan Hasil Belajar Matematika SD. Primary: Jurnal Pendidikan Guru Sekolah Dasar. 7(1), 40-47

Hasannah, N., Sofelma, S. \& Syarifuddin, H. (2021). Peningkatan Aktivitas dan Berpikir Kritis pada Pembelajaran Matematika Berasis Pendekatan PBL di Sekolah Dasar. Jurnal Basicedu. 5(2), 974-982

Howard, J. (2002). Technology-enhanced project-based learning in teacher education: Addressing the goals of transfer. Journal of Technology and Teacher Education, 10(3), 343-364

Ismiyono, I. (2020). Upaya peningkatan hasil belajar siswa dalam pembelajaran daring melalui penerapan model problem based learning siswa kelas IV SD Negeri Sambeng tahun 2020/2021. Jurnal Kualita Pendidikan, 1 (3): 63-67.

Kemmis, S. \& Mc. Taggart, R. 1988. The Action Research Planner. Victoria: Deakin, University Press.

Krismiati, A. (2008). Pembelajaran berbasis masalah berbantuan Cabry II dalam meningkatkan kemampuan pemecahan dan berpikir kritis siswa. Tesis tidak diterbitkan. Universitas Pendidikan Indonesia. Bandung.

Mashuri, S., Djidu, H., \& Ningrum, R. K. (2019). Problem-based learning dalam pembelajaran matematika: Upaya guru untuk meningkatkan minat dan prestasi belajar siswa. PYTHAGORAS: Jurnal Pendidikan Matematika, 14(2), 112-125. doi: https://doi.org/10.21831/pg.v14i2.25034

Mulyanto, H. Gunarhadi, G. \& Indriayu, M. (2018). The Effect of Problem Based Learning Model on Student Mathematics Learning Outcomes Viewed from Critical Thinking Skills. International Journal of Educational Research Review. 3(2), 37-45. https://doi.org/10.24331/ijere.408454

Maret, M. \& Syarifuddin, H. (2021). Penggunaan Model Pembelajaran Problem Based Learning Untuk Meningkatkan Aktivitas dan Hasil Belajar Matematika Siswa Kelas VI Sekolah Dasar JEMS (Jurnal Edukasi Matematika dan Sains), 9(1), 106-112 DOI: 10.25273/jems.v9i1.8746 106 
Meke, K. D. P., et al (2018). The Effectiveness of Problem-based Learning Using Manipulative Materials Approach on Cognitive Ability in Mathematics Learning. J. Phys.: Conf. Ser. 1097012135

Meke, K. D. P., et al 2019. Problem based learning using manipulative materials to improve student interest of mathematics learning. J. Phys.: Conf. Ser. 1157032099

Meke, K. D. P., Wondo, M. T. S. \& Wutsqa, D. U. (2020). Pembelajaran problem based learning dengan penggunaan bahan manipulatif ditinjau dari minat belajar matematika. Jurnal Penelitian Pembelajaran Matematika. 13(2), 164-177.

Meke, K. D. P. \& Wondo, M. (2020). Pengembangan Perangkat Pembelajaran Model Problem Based Learning Melalui Penggunaan Bahan Manipulatif. Jurnal Kependidikan: Jurnal Hasil Penelitian dan Kajian Kepustakaan di Bidang Pendidikan, Pengajaran dan Pembelajaran, 6(3), 588-600. https://doi.org/10.33394/jk.v6i3.2861

Moleong, Lexy J. 2007. Metodologi Penelitian Kualitatif. Bandung: Remaja. Rosdakarya.

Nurlaily, V. A., Soegiyanto, H. \& Usodo, B. (2019). Elementary School Teacher's Obstacles In The Implementation Of Problem-Based Learning Model In Mathematics Learning. Journal on Mathematics Education. 10( 2), pp. 229-238 229

Padmavathy, R.D., \& Mareesh, K. (2013). Effectiveness of problem based learning in mathematics. International Multidisciplinary e-Journal, 2(1), 45-51.

Pratama, L. D., Lestari, W. \& Jailani, J. (2018). Implementasi Pendekatan Saintifik Melalui Problem Based Learning Terhadap Minat dan Prestasi Belajar Matematika. Jurnal Matematika dan Pendidikan Matematika. 3(1), 11-21

Rahmah, N. (2013). Hakikat pendidikan matematika. Al-Khwarizmi : Jurnal Pendidikan Matematika dan Ilmu Pengetahuan Alam. 1(2), 1- 8.

Rahmadani, N. N. (2017). Peningkatan Aktivitas Belajar Matematika Melalui Pendekatan Problem Based Learning Bagi Siswa Kelasa 4 SD. Scholaria:Jurnal Pendidikan Dan Kebudayaan, 3, 249-250

Rusman. (2014). Model-model Pembelajaran (Mengembangkan Profesionalisme. Guru). Jakarta: Raja Grafindo Persada.

Sagala, S. (2011). Konsep dan Makna Pembelajaran. Bandung: Alfabeta.

Schmidt, H. G., Rotgans, J. I. \& Yew, E. H. (2011). The process of problem-based learning: what works and why. Med Educ. 45(8):792-806. doi: 10.1111/j.1365-2923.2011.04035.x. PMID: 21752076

Suhirman., Prayogi, S., \& Asy'ari, M. (2021). Problem-Based Learning with CharacterEmphasis and Naturalist Intelligence: Examining Students Critical Thinking and Curiosity. International Journal of Instruction, 14(2), 217-232.

Suradijono, SHR. (2004). Problem Based Learning. Apa dan bagaimana? Makalah Seminar Penumbuhan Inovasi Sistem Pembelajaran Pendekatan Problem Based Learning berbasis ICT. Yogyakarta. 
Penerapan Problem Based Learning Dalam Meningkatkan Hasil Belajar Matematika Siswa Sekolah Dasar

Nama Theodosia Ndole ${ }^{1}$, Maria Ana ${ }^{2}$

Jupika: Jurnal Pendidikan Matematika, Volume 4. Nomor 1. Maret 2021. Hal. 32-41

Suwangsih, E. \& Tiurlina. (2006). Model Pembelajaran Matematika. Bandung: UPI Press.

Valentine, K. D. \& Bolyard, J. (2019). Lived Moments of Shift in Prospective Elementary Teachers' Mathematical Learning. Journal for Research in Mathematics Education. 50(4), 436-463. https://doi.org/10.5951/jresematheduc.50.4.0436

Wahyudin. (2008). Pembelajaran dan Model-Model Pembelajaran. Bandung: UPI

Wondo, M. (2017). Pengembangan perangkat pembelajaran matematika SMP kelas VIII semester genap dengan model problem-based learning. PYTHAGORAS: Jurnal Pendidikan Matematika, 12(1), 76-86. http://dx.doi.org/10.21831/pg.v12i1.14056 